\title{
Antidiabetic Activity of Aloe vera Leaves
}

\author{
Alethia Muñiz-Ramirez $\mathbb{D}^{1},{ }^{1}$ Rosa M. Perez, ${ }^{2}$ Efren Garcia, ${ }^{3}$ and Fabiola E. Garcia ${ }^{4}$ \\ ${ }^{1}$ CONACYT-IPICYT/CIIDZA, Camino a la Presa de San José 2055, Col. Lomas 4 Sección, CP 78216 San Luis Potosí S.L.P, Mexico \\ ${ }^{2}$ Laboratorio de Investigación de Productos Naturales, Escuela Superior de Ingeniería Química e Industrias Extractivas, \\ Instituto Politécnico Nacional, Av. Instituto Politécnico Nacional S/N, Unidad Profesional Adolfo Lopez Mateos, \\ CP 07708 Ciudad de Mexico, Mexico \\ ${ }^{3}$ Laboratorio de Química Supramolecular y Nanociencias, Instituto Politécnico Nacional, Acueducto S/N, \\ Barrio la laguna Ticomán, CP 07340 Ciudad de México, Mexico \\ ${ }^{4}$ Facultad de Ciencias Químicas, Universidad Autónoma de San Luis Potosí, Av. Dr. Manuel Nava No. 6-Zona Universitaria, \\ CP 78210 San Luis Potosí S.L.P, Mexico
}

Correspondence should be addressed to Alethia Muñiz-Ramirez; alethia.muniz@ipicyt.edu.mx

Received 19 December 2019; Revised 25 February 2020; Accepted 27 March 2020; Published 25 May 2020

Academic Editor: Ronald Sherman

Copyright (c) 2020 Alethia Muñiz-Ramirez et al. This is an open access article distributed under the Creative Commons Attribution License, which permits unrestricted use, distribution, and reproduction in any medium, provided the original work is properly cited.

\begin{abstract}
This research evaluated the potential of using the methanol extract of Aloe vera (L.) Burm.f (AVM) to prevent the formation of AGEs by means of the BSA/glucose assay, BSA-methylglyoxal assay, arginine-methylglyoxal assay, fructosamine, NE-(carboxymethyl) lysine (CML), thiol groups, and carbonyl protein in vitro. The effect of AVM was also evaluated with regard to inhibiting the enzymes $\alpha$-amylase, $\alpha$-glucosidase, and pancreatic lipase. For this, the plant was dried, ground, and subsequently macerated with methanol. Aloe vera methanol extract (AVM) significantly decreased the formation of AGEs, as well as the formation of fructosamine, CML, and carbonyl protein. The concentration of $5 \mathrm{mg} / \mathrm{ml}$ of AVM presented the best results. AVM significantly inhibited the $\alpha$-amylase and $\alpha$-glucosidase enzymes. As regards the content of thiol groups, a significant increase was observed during the four weeks of the experiment. So, we can conclude that Aloe vera methanol extract decreases the formation of AGEs and may inhibit the increase in postprandial glucose, suggesting that AVM can prevent diabetes complications associated with AGE.
\end{abstract}

\section{Introduction}

Protein glycation is considered one of the main causes of complications of diabetes, such as vasculopathy, retinopathy, nephropathy and neuropathy, cataracts, and chronic kidney disease [1]. The glycation of proteins brings about the formation of advanced glycation end products (AGEs), which modify the structure of proteins and alter enzymatic activity [2]. AGEs are formed by the nonenzymatic reaction of the free amino group of a protein with the carbonyl of a sugar or a reducing aldehyde (called the Maillard reaction) [3], resulting in the formation of Schiff bases, subsequently through a series of reactions, and fluorescent compounds such as pentosidine and nonfluorescent compounds such as carboxymethyl lysine (CML) are formed [4]. Some AGEs, such as CML and pentosidine, have become biomarkers for glycooxidizing damage [5]. Therefore, taking into account the pathological implications of glycation, it becomes essential to discover inhibitors of protein glycation, which may help reduce and/or prevent complications in diabetes mellitus [2]. For centuries, herbal medicines have been widely used to treat a wide variety of diseases. To date, many of these plants are still used as a first alternative to cure certain diseases in developing countries around the world due to the few side effects they present; it has also been reported that around $20 \%$ of the medicines used throughout the world come from plants [6]. In this context, there is a growing interest in discovering safe and nontoxic plant sources to find alternative or complementary medicines that help the treatment of various chronic diseases such as 
diabetes mellitus. Aloe vera (L.) Burm.f. has been used by different cultures such as the Egyptian, Indian, Chinese, and European cultures for more than 5000 years due to its extraordinary medicinal properties $[7,8]$. The genus Aloe grows in arid, tropical, and subtropical areas; this genus includes approximately 450 species. It is a succulent plant with no stem or a short stem and can grow to be $60-100 \mathrm{~cm}$ high; its leaves are fleshy, thick, triangular, and spiny [8], which gives the appearance of cactus, but in fact it belongs to the lilac (Liliacea) family. Its leaves have the ability to retain water, which allows the plant to survive in environments with long periods of drought, where most of the vegetation disappears [9]. It contains more than 70 active compounds [7], including vitamins, minerals, enzymes, polysaccharides, phenolic compounds, and organic acids. It has been reported that the polysaccharides present in the A. vera gel have therapeutic properties such as anti-inflammatory, healing, antibacterial, antioxidant, anticarcinogenic, antidiabetic, and antiaging properties, among others [8,9]. Taking into account the pathological effects that glycation brings about, it is very important to find compounds that inhibit the nonenzymatic glycation of proteins to help prevent the generation of secondary complications, which is why this study's objective was to assess the capacity of the methanol extract of Aloe vera (AVM) to inhibit the protein glycation reaction by means of the BSA/glucose assay.

\section{Materials and Methods}

2.1. Collection of Raw Materials. Aloe vera was collected in May 2018, in the municipality of Armadillo, San Luis Potosí. A specimen was taken to the herbarium of the Autonomous Metropolitan University for future reference (specimen number ARC-53578).

2.2. Preparation of the Extract. Three hundred grams of the whole leaf was dried and pulverized in a mechanical mill, obtaining $110 \mathrm{~g}$ of dry weight. The powdered material was extracted with $3 \mathrm{~L}$ of methanol using a Soxhlet apparatus. The extract (AVM) was filtered and concentrated by a rotary vacuum evaporator for the complete removal of solvents.

\subsection{Inhibition Tests for the Formation of Advanced Glycation End Products}

2.3.1. In vitro Glycation of Bovine Albumin. The glycation of the BSA was carried out using the method used by Gutierrez et al. [10] with some modifications. The AVM extract was dissolved in DMSO (0.031-0.500 mg/ml), adding $10 \mathrm{mg} / \mathrm{ml}$ of BSA, 1.1 M glucose, $0.1 \mathrm{M}$ phosphate buffer at $\mathrm{pH} 7.4$, and $0.2 \%$ sodium azide. The solution was incubated at $37^{\circ} \mathrm{C}$ for four weeks. The formation of the glycated BSA was determined at an excitation wavelength of $355 \mathrm{~nm}$ and emission of $460 \mathrm{~nm}$; aminoguanidine was used as a positive control.

2.3.2. Determination of Fructosamine. The AVM extract was dissolved in DMSO $(0.031-0.500 \mathrm{mg} / \mathrm{ml})$, adding $10 \mathrm{mg} / \mathrm{ml}$ of BSA, 1.1 M glucose, 0.1 M phosphate buffer at $\mathrm{pH} 7.4$, and $0.2 \%$ sodium azide. The solution was incubated at $37^{\circ} \mathrm{C}$ for four weeks. After four weeks of incubation, the fructosamine concentration of the Amadori product was assessed by the nitroblue tetrazolium assay (NTB) [11]. $10 \mu \mathrm{l}$ of glycated BSA was incubated with $90 \mu \mathrm{l}$ of $0.5 \mathrm{mM}$ NTB, in $0.1 \mathrm{M}$ carbonate buffer at a $\mathrm{pH}$ of 10.4 at $37^{\circ} \mathrm{C}$. After 10 to 15 minutes, the absorbance was read at $530 \mathrm{~nm}$. The concentration of fructosamine was calculated by comparing it with 1-deoxy1-morpholino-fructose (1-DMF), which was used as standard.

2.3.3. BSA-Methylglyoxal Assay. This test was performed to evaluate the middle stage of protein glycation. Methylglyoxal was added $(60 \mathrm{mM}, 1 \mathrm{ml})$, at different concentrations of $\operatorname{AVM}(0.30,0.60,1.2,2.5$ and $5 \mathrm{mg} / \mathrm{ml})$ and catechin $(1.5 \mathrm{mg} /$ $\mathrm{ml}, 1 \mathrm{ml})$, in sodium phosphate buffer $(50 \mathrm{mM}, \mathrm{pH} 7.4)$ and sodium azide $(0.02 \%)$ at $37^{\circ} \mathrm{C}$ for $2 \mathrm{~h}$. BSA $(30 \mathrm{mg} / \mathrm{ml}, 1 \mathrm{ml})$ was subsequently added to the mixture and incubated at $37^{\circ}$ for six days. The phosphate buffer $(1 \mathrm{ml})$ was used as a negative control without the addition of AVM extract. As a positive control, aminoguanidine $(10 \mathrm{mM}$, final concentration) was used. After the incubation time, the samples were read in a microplate reader at $340 \mathrm{~nm}$ excitation and $380 \mathrm{~nm}$ emission [12]. The percentage of inhibition of AGEs was calculated using

$$
\text { percentage inhibition }=1-\left(\frac{\text { fluorescent intensity with inhibitor }}{\text { fluorescent intensity without inhibitor }}\right) \times 100 \text {. }
$$

2.3.4. Arginine-Methylglyoxal Assay. This test analyzes the main and specific source of AGEs formation. Methylglyoxal was added $(60 \mathrm{mM}, 1 \mathrm{ml})$, at different concentrations of $\operatorname{AVM}(0.30,0.60,1.2,2.5$, and $5 \mathrm{mg} / \mathrm{ml})$ and catechin $(1.5 \mathrm{mg} / \mathrm{ml}, 1 \mathrm{ml})$, in sodium phosphate buffer $(50 \mathrm{mM}, \mathrm{pH}$ 7.4 ) and sodium azide $(0.02 \%)$ at $37^{\circ} \mathrm{C}$ for $2 \mathrm{~h}$. Subsequently, arginine $(60 \mathrm{mM}, 1 \mathrm{ml})$ was added to the different samples and incubated at $37^{\circ} \mathrm{C}$ for six days. As a negative control, phosphate buffer $(1 \mathrm{ml})$ was used without the addition of AVM extract. As a positive control, aminoguanidine
(10 mM, final concentration) was used. After the incubation time, the samples were read on a microplate reader at $340 \mathrm{~nm}$ excitation and $380 \mathrm{~nm}$ emission [12]. The percentage of inhibition of AGEs was calculated using (1).

2.3.5. Determination of $N \mathcal{E}$-(Carboxymethyl) Lysine. At the end of the fourth week of incubation, the $\mathrm{N} \varepsilon$-(carboxymethyl) lysine (CML) was determined, and a major antigenic AGE structure was determined by using the enzyme 
linked immunosorbant assay (ELISA) kit. The concentration of CML was calculated by using the standard CML-BSA curve from the assay kit.

2.4. Determination of Protein Carbonyl Content. After four weeks of incubation, the content of the carbonyl group was determined in glycosylated BSA, which is a marker of oxidative protein damage, using the method described by Joglekar et al. [2] with some modifications. $800 \mu \mathrm{l}$ of $10 \mathrm{mM}$ 2-4-dinitrophenylhydrazine (DNPH) in $2.5 \mathrm{M}$ HCL was added to $200 \mu \mathrm{l}$ of glycated samples. The samples were allowed to incubate in the dark for $1 \mathrm{~h}$, and then the proteins were precipitated using $1 \mathrm{ml}$ of trichloroacetic acid. (TCA) at $20 \%(\mathrm{p} / \mathrm{V})$, leaving the samples on ice for five minutes, and they were then centrifuged at $10,000 \mathrm{~g}$ for $10 \mathrm{~min}$ at $4^{\circ} \mathrm{C}$. The supernatant was washed three times using $500 \mu \mathrm{l}$ of a mixture of ethanol/ethyl acetate $(1: 1)$, and then the protein supernatant was dissolved in $500 \mu \mathrm{l}$ of $6 \mathrm{M}$ guanidine hydrochloride. The absorbance reading was $370 \mathrm{~nm}$. The carbonyl group concentration of the samples was calculated using the absorption coefficient $\left(\varepsilon=22,000 \mathrm{M}^{-1} * \mathrm{~cm}^{-1}\right)$. The results were expressed as nmol carbonyl/mg protein.

2.5. Thiol Group Estimation. After four weeks of incubation, free thiol groups were determined in glycated BSA using the method described by [11] with some modifications. $70 \mu \mathrm{l}$ of

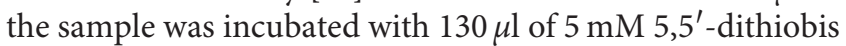
(2-nitrobenzoic acid) (DTNB) in $0.1 \mathrm{M} \mathrm{PBS,} \mathrm{pH} 7.4$ at $25^{\circ} \mathrm{C}$ for 15 minutes. After the absorbance of the samples was read at $412 \mathrm{~nm}$, the concentration of free thiol was calculated using a standard curve of L-cysteine. The results were expressed as $\mathrm{nmol} / \mathrm{mg}$ of protein.

\subsection{Enzymatic Assays}

2.6.1. Inhibition of $\alpha$-Amylase. The inhibition of $\alpha$-amylase activity was performed using a modified method with 2-chloro-4-nitrophenyl-4- $\beta$-D-galactopyranosylmaltoside (GalG2CNP) as substrate and saliva fraction enriched with $\alpha$-amylase (HSA-f) [13]. The HSA-f was diluted 100-fold in $50 \mathrm{mmol} \mathrm{L}^{-1} 2$-(N-morpholino) ethanesulfonic acid (MES) buffer containing $5 \mathrm{mmol} \mathrm{L}^{-1} \mathrm{CaCl}_{2}, 140 \mathrm{mmol} \mathrm{L}^{-1}$ potassium thiocyanate, and $300 \mathrm{mmol} \mathrm{L}^{-1} \mathrm{NaCl}$ ( $\mathrm{pH}$ 6.0). Different concentrations of AVM $(0.30,0.60,1.2,2.5$, and $5 \mathrm{mg} / \mathrm{ml}$ ) previously diluted in 5\% DMSO were incubated with HSA-f $\left(1: 10 \mathrm{v} \mathrm{v}^{-1}\right)$ at $37^{\circ} \mathrm{C}$ for $30 \mathrm{~min}$. The reaction was initiated by adding $12 \mathrm{mmol} \mathrm{L}^{-1}$ GalG2CNP substrate; increases in absorbance (i.e., CNP release) were measured at $37^{\circ} \mathrm{C}$ at $405 \mathrm{~nm}$. This assay was also carried out with acarbose (purity $>95 \%$ ) as a positive control and 5\% DMSO as a negative control. The results were presented as a percentage of $\alpha$-amylase inhibition (AI), calculated according to the following:

$$
\mathrm{AI}(\%)=\frac{\left(A_{\mathrm{nc}}-A_{\text {sample }}\right)}{A_{\mathrm{nc}}} \times 100 \text {, }
$$

where $A_{\mathrm{nc}}$ is the absorbance of negative control and $A_{\text {sample }}$ is the absorbance of the extract incubated with HSA-f.

2.6.2. Inhibition of $\alpha$-Glucosidase. The inhibition of $\alpha$-glucosidase activity was performed using a modified method with 4-nitrophenyl $\alpha$-D-glucopyranoside (p-NPG) as substrate and $\alpha$-glucosidase-enriched fraction from intestinal acetone powders from rats (AG-f) [13]. Different concentrations of $\operatorname{AVM}(0.30,0.60,1.2,2.5$, and $5 \mathrm{mg} / \mathrm{ml})$, previously diluted in 5\% DMSO, were incubated with AG-f and $1.5 \mathrm{mmol} \mathrm{L}^{-1}$ reduced glutathione (diluted in $50 \mathrm{mmol} \mathrm{L}^{-1}$ phosphate buffer, $\mathrm{pH} \mathrm{6.8)} \mathrm{for} 20 \mathrm{~min}$ at $37^{\circ} \mathrm{C}$. The reaction was started by adding $4 \mathrm{mmol} \mathrm{L}^{-1} \mathrm{p}-\mathrm{NPG}$ (diluted in $50 \mathrm{mmol} \mathrm{L}^{-1}$ phosphate buffer, $\mathrm{pH}$ 6.8) and absorbance values were measured at $405 \mathrm{~nm}$ for $30 \mathrm{~min}$ at $37^{\circ} \mathrm{C}$. This assay was also carried out with acarbose (purity $>95 \%$ ) as a positive control and 5\% DMSO as a negative control. The results were presented as a percentage of $\alpha$-glucosidase inhibition (GsI), calculated according to the following:

$$
\operatorname{GsI}(\%)=\frac{\left(A_{\mathrm{nc}}-A_{\text {sample }}\right)}{A_{\mathrm{nc}}} \times 100,
$$

where $A_{\mathrm{nc}}$ is the absorbance of negative control and $A_{\text {sample }}$ is the absorbance of the extract incubated with AG-f.

2.6.3. Inhibition of Pancreatic Lipase. The inhibition of pancreatic lipase activity was performed using a modified method with p-nitrophenyl palmitate ( $\mathrm{p}$-NPP) as substrate and porcine pancreatic lipase (PL) (type II, Sigma) [14]. Different concentrations of AVM $(0.30,0.60,1.2,2.5$, and $5 \mathrm{mg} / \mathrm{ml}$ ), previously diluted in 5\% DMSO, were incubated with $10 \mathrm{~g} \mathrm{~L}^{-1} \mathrm{PL}$ (diluted in $50 \mathrm{mM}$ Tris- $\mathrm{HCl}$ buffer $\mathrm{pH} 8.0$, containing $10 \mathrm{mmol} \mathrm{L}^{-1} \mathrm{CaCl}_{2}$ and $25 \mathrm{mmol} \mathrm{L}^{-1} \mathrm{NaCl}$ ) for $20 \mathrm{~min}$ at $37^{\circ} \mathrm{C}$. The reaction was started by adding $0.8 \mathrm{mmol} \mathrm{L}^{-1} \mathrm{p}$-NPP substrate (diluted in $10 \%$ isopropanol and $50 \mathrm{mmol} \mathrm{L}^{-1}$ Tris- $\mathrm{HCl}$ buffer, containing $10 \mathrm{mmol} \mathrm{L}^{-1}$ $\mathrm{CaCl}_{2}, 25 \mathrm{mmol} \mathrm{L}^{-1} \mathrm{NaCl}$, and $0.5 \%$ Triton X-100), and absorbance values were measured at $410 \mathrm{~nm}$ for $30 \mathrm{~min}$ at $30^{\circ} \mathrm{C}$. This assay was also carried out with orlistat (purity $>98 \%$ ) as a positive control and 5\% DMSO as a negative control. The results were presented as a percentage of lipase inhibition (LI), calculated according to the following:

$$
\mathrm{LI}(\%)=\frac{\left(A_{\mathrm{nc}}-A_{\text {sample }}\right)}{A_{\mathrm{nc}}} \times 100,
$$

where $A_{\mathrm{nc}}$ is the absorbance of negative control and $A_{\text {sample }}$ is the absorbance of the extract incubated with PL.

2.7. Statistical Analysis. The results were expressed as the mean \pm standard error of the mean (SEM) $(n=3)$. The statistical significance of the results was evaluated by using one-way ANOVA. The least significant difference (LSD) test was used for mean comparisons, and $P<0.05$ was statistically significant. 


\section{Results}

\subsection{Inhibition Tests for the Formation of Advanced Glycation End Products}

3.1.1. In vitro Glycation of Bovine Albumin. In Figure 1, the fluorescence intensity is shown during the four weeks of incubation. The results show that fluorescence was significantly increased over the weeks in the BSA/glucose system compared to the groups incubated with BSA/glucose/AVM at different concentrations, where a significant decrease in fluorescence was observed depending on the concentration. After four weeks of the experiment, the BSA/glucose/AVM group $(5 \mathrm{mg} / \mathrm{ml})$ showed the greatest decrease in fluorescence intensity $(85.64 \%)$, while the AG $(5 \mathrm{mg} / \mathrm{ml})$ showed a decrease of $87.94 \%$ in comparison with the BSA glycated in the same time interval.

3.1.2. Determination of Fructosamine. The effect of AVM on fructosamine levels during the four weeks is shown in Table 1 . The results show that the concentration of fructosamine in the glycosylated BSA increased significantly over time. By adding AVM to different concentrations, fructosamine levels increased at a lower rate during the four weeks of the test. In the fourth week, a fructosamine value of $77.5 \mathrm{mM}$ was observed when using the BSA/glucose/AVM system $(5 \mathrm{mg} / \mathrm{ml})$, compared to the BSA/glucose/AG system, which showed a value of $75.8 \mathrm{mM}$. The glycated BSA showed a value of $119.6 \mathrm{mM}$ in the same time interval.

3.1.3. BSA-Methylglyoxal Assay. The effect of AVM at different concentrations in the BSA-methylglyoxal test is shown in Figure 2. It can be observed that the greatest inhibition was presented when using the BSA/glucose/AVM system $(5 \mathrm{mg} / \mathrm{ml})$ showing an inhibition of $65 \%$, compared to the BSA/glucose/AG system $(5 \mathrm{mg} / \mathrm{ml})$ which showed an inhibition of $91 \%$.

3.1.4. Arginine-Methylglyoxal Assay. The antiglycation test using the arginine-methylglyoxal model showed that the $\mathrm{BSA} /$ glucose/AVM system $(5 \mathrm{mg} / \mathrm{ml})$ inhibited the generation of fluorescent AGEs at 65\% (Figure 3). The BSA/glucose/AG system $(5 \mathrm{mg} / \mathrm{ml})$ showed an inhibition percentage of $80 \%$.

3.1.5. Ne-(Carboxymethyl) Lysine. The effect of AVM on the inhibition of $\mathrm{N} \varepsilon$-(carboxymethyl) lysine (CML) after four weeks of incubation is shown in Figure 4, where it can be seen that the concentration of CML in the BSA/glucose system increased. During the experiment, when evaluating the results of the BSA/AVM/glucose system, it was observed that the $\mathrm{CML}$ values were concentration-dependent, obtaining a significant $73 \%$ inhibition in the formation of $\mathrm{CML}$ at a concentration of $5 \% \mathrm{mg} / \mathrm{ml}$, compared to the BSA/ AG/glucose system $(5 \mathrm{mg} / \mathrm{ml})$, which showed a $74 \%$ inhibition compared to the glycated BSA.
3.2. Determination of Protein Carbonyl Content. Table 2 shows the protein carbonyl content during the four weeks. When observing the glycated BSA, an increase in protein carbonyl content can be seen during the four weeks of the experiment. While adding AVM, the BSA/glucose system at different concentrations showed a significant decrease in protein carbonyl content during the four weeks that the experiment lasted obtaining the highest decrease in the BSA/ glucose/AVM system at a concentration of $5 \mathrm{mg} / \mathrm{ml}$, which showed a value of $82.88 \mathrm{nmol} / \mathrm{mg}$ protein. The BSA/glucose/ AG system and the glycated BSA showed values of $82.56 \mathrm{nmol} / \mathrm{mg}$ protein and $89.15 \mathrm{nmol} / \mathrm{mg}$ protein, respectively, in the same time interval.

3.3. Thiol Group Estimation. The effect of AVM during the four weeks at different concentrations is shown in Table 3. The BSA/glucose system showed a significant increase in thiol groups throughout the experiment. By adding AVM to the BSA/glucose system, a significant decrease in thiol-dependent groups can be observed. The greatest decrease was obtained at a concentration of $5 \mathrm{mg} / \mathrm{ml}(89.12 \mathrm{nmol} / \mathrm{mg}$ protein) at four weeks of the experiment, while the BSA/glucose/AG and glycated BSA system showed values of 78.08 and $70.05 \mathrm{nmol} /$ $\mathrm{mg}$ protein, respectively, in the same time interval.

\subsection{Enzymatic Assays}

3.4.1. $\alpha$-Amylase, $\alpha$-Glucosidase, and Lipase Inhibition Activity. Figure 5 shows the inhibitory effect of AVM on the activity of the alpha-amylase enzyme. The AVM concentration of $5 \mathrm{mg} / \mathrm{ml}$ showed a significant inhibition of $87 \%$, compared to acarbose $(5 \mathrm{mg} / \mathrm{ml})$ which was used as a positive control and showed an inhibition percentage of $97 \%$. The concentrations of 0.60 and $0.30 \mathrm{mg} / \mathrm{ml}$ AVM did not show inhibitory activity. Regarding the inhibition of the $\alpha$-glucosidase enzyme (Figure 5), the concentration of $5 \mathrm{mg} / \mathrm{ml}$ of AVM significantly inhibited the activity of the enzyme by $66 \%$, compared to acarbose at the same concentration, which presented an $85 \%$ inhibition. The concentrations of 0.60 and $0.30 \mathrm{mg} / \mathrm{ml}$ of the AVM extract showed no inhibition of the enzyme $\alpha$-glucosidase. Regarding the inhibition of pancreatic lipase, the concentrations of 2.5 and $5 \mathrm{mg} / \mathrm{ml}$ of AVM showed an inhibitory activity of $9 \%$ and $15 \%$, respectively (Figure 6), compared to the control drug, which presented an inhibition of $99 \%$.

\section{Discussion}

AGEs are a group of compounds that are formed by the nonenzymatic reaction of reducing sugars and metabolites related to proteins and amino acids to produce Schiff bases. Subsequently, Amadori products (such as fructosamine) are formed which degrade into dicarbonyl compounds to finally produce stable AGEs $[1,12,15]$. AVM reduced fructosamine levels, which are associated with decreased AGE formation. The reduction of fructosamine, therefore, is a therapeutic way to delay incident vascular complications [16]. To this end, the capacity of AVM to inhibit the protein glycation reaction using the BSA/glucose system was evaluated. It was 


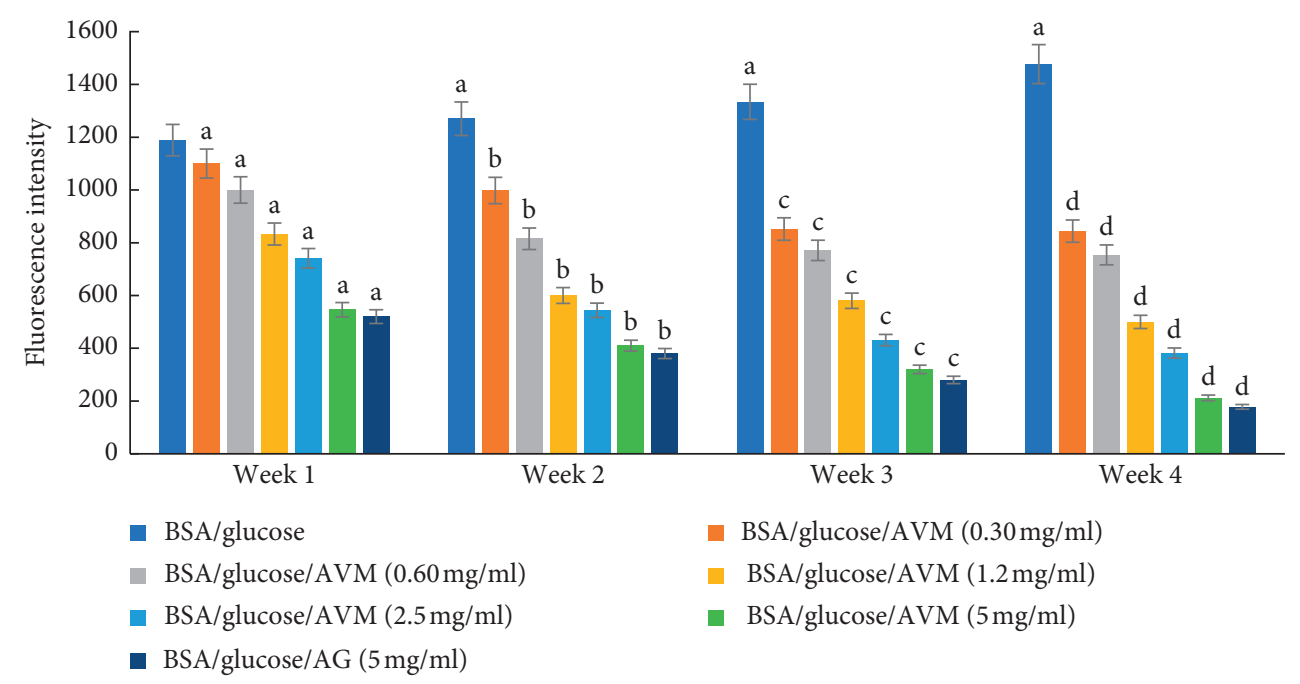

FIGURE 1: Effects of AVM extract on formation of fluorescent advanced glycation end products (AGEs) in BSA incubated with glucose. Each value represents the mean $\pm \mathrm{SE}(n=3) .{ }^{\mathrm{a}} p<0.05$ when compared to BSA/glucose at week one; ${ }^{\mathrm{b}} p<0.05$ when compared to BSA/glucose at week two; ${ }^{c} p<0.05$ when compared to BSA/glucose at week three; ${ }^{\mathrm{d}} p<0.05$ when compared to BSA/glucose at week four.

TABLE 1: Effect of AVM on fructosamine levels during four weeks of incubation using the BSA/glucose system.

\begin{tabular}{|c|c|c|c|c|}
\hline \multirow{2}{*}{ Experimental groups } & \multicolumn{4}{|c|}{ Fructosamine $(\mathrm{mM})$} \\
\hline & Week 1 & Week 2 & Week 3 & Week 4 \\
\hline BSA/glucose & $87.2 \pm 0.8$ & $97.9 \pm 0.9$ & $108.5 \pm 1.6$ & $119.6 \pm 1.2$ \\
\hline BSA/glucose/AVM $(0.30 \mathrm{mg} / \mathrm{ml})$ & $86.7 \pm 1.2$ & $85.5 \pm 1.3^{\mathrm{a}}$ & $86.3 \pm 0.8^{\mathrm{a}}$ & $86.9 \pm 1.4^{\mathrm{a}}$ \\
\hline BSA/glucose/AVM $(0.60 \mathrm{mg} / \mathrm{ml})$ & $83.4 \pm 0.8^{\mathrm{a}}$ & $84.3 \pm 0.5^{\mathrm{b}}$ & $85.1 \pm 1.2^{\mathrm{c}}$ & $85.6 \pm 1.7^{\mathrm{d}}$ \\
\hline BSA/glucose/AVM (1.2 mg/ml) & $80.1 \pm 1.1^{\mathrm{a}}$ & $82.7 \pm 1.3^{\mathrm{b}}$ & $83.5 \pm 0.9^{c}$ & $84.1 \pm 1.3^{\mathrm{d}}$ \\
\hline $\mathrm{BSA} /$ glucose $/ \mathrm{AVM}(2.5 \mathrm{mg} / \mathrm{ml})$ & $77.8 \pm 1.2^{\mathrm{a}}$ & $79.2 \pm 1.8^{\mathrm{b}}$ & $81.4 \pm 0.5^{\mathrm{c}}$ & $82.7 \pm 1.4^{\mathrm{d}}$ \\
\hline $\mathrm{BSA} /$ glucose/AVM $(5 \mathrm{mg} / \mathrm{ml})$ & $74.4 \pm 1.5^{\mathrm{a}}$ & $75.4 \pm 1.2^{\mathrm{b}}$ & $77.1 \pm 0.6^{\mathrm{c}}$ & $77.5 \pm 1.4^{\mathrm{d}}$ \\
\hline BSA/glucose/AG (5 mg/ml) & $72.1 \pm 1.4^{\mathrm{a}}$ & $73.9 \pm 1.5^{\mathrm{b}}$ & $74.5 \pm 1.2^{\mathrm{c}}$ & $75.8 \pm 0.9^{\mathrm{d}}$ \\
\hline
\end{tabular}

Results are expressed as mean \pm SEM $(n=3) .{ }^{\mathrm{a}} p<0.05$ when compared to BSA/glucose at week one; ${ }^{\mathrm{b}} p<0.05$ when compared to BSA/glucose at week two; ${ }^{c} p<0.05$ when compared to BSA/glucose at week three; ${ }^{\mathrm{d}} p<0.05$ when compared to BSA/fructose at week four.

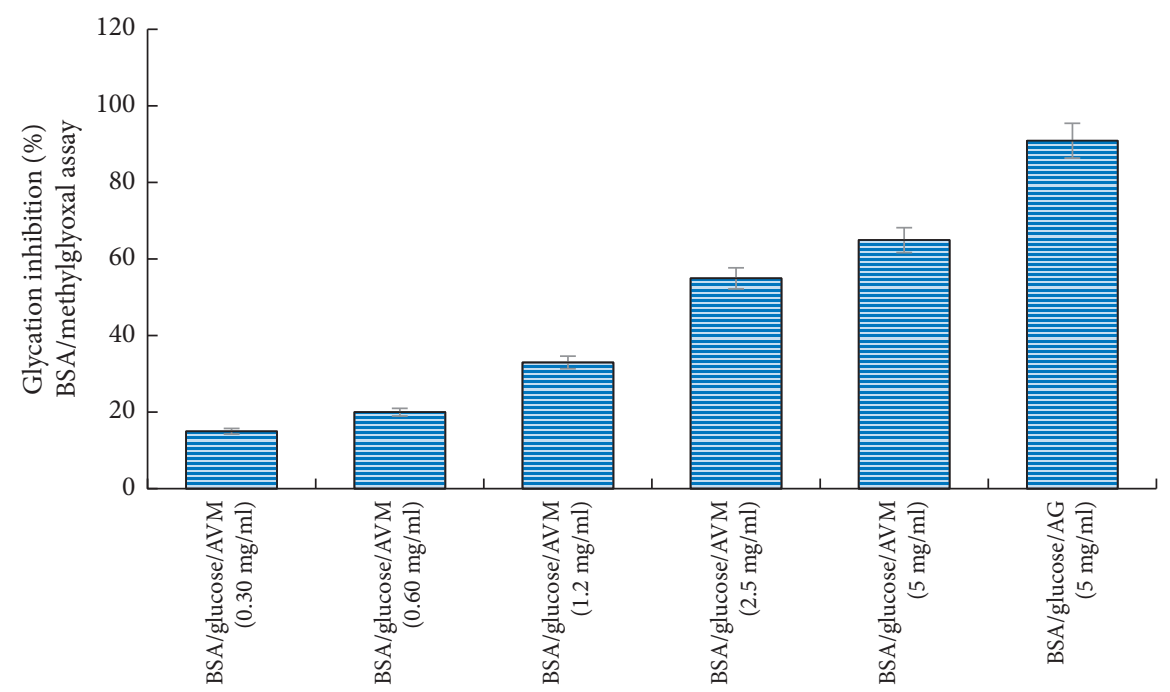

FIgURe 2: Glycation inhibitory activity analysis of the methanol extract from Aloe vera in BSA-methylglyoxal model. Values (mean\pm standard deviation) are expressed as a percentage of glycation inhibition. AVM: methanol extract from Aloe vera.

observed that AVM can inhibit the glycation reaction (which is related to complications in diabetes) in a way similar to the aminoguanidine (AG) used as a control. Since the formation of AGEs is favored by oxidative reactions, AVM could have inhibited them by reducing the formation of reactive oxygen species (ROS), or by eliminating the ROS formed in vitro by 


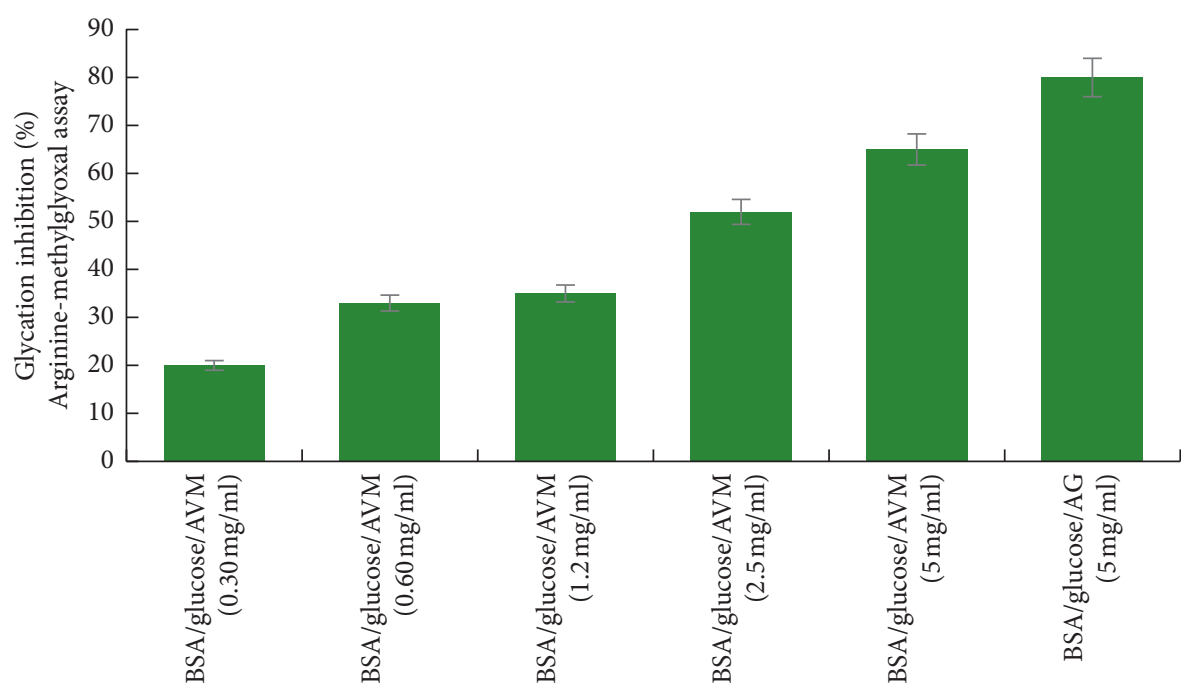

FIGURE 3: Glycation inhibitory activity analysis of the methanol extract from Aloe vera (AVM) in arginine-methylglyoxal model. Values (mean \pm standard deviation) are expressed as a percentage of glycation inhibition. AVM: methanol extract from Aloe vera.

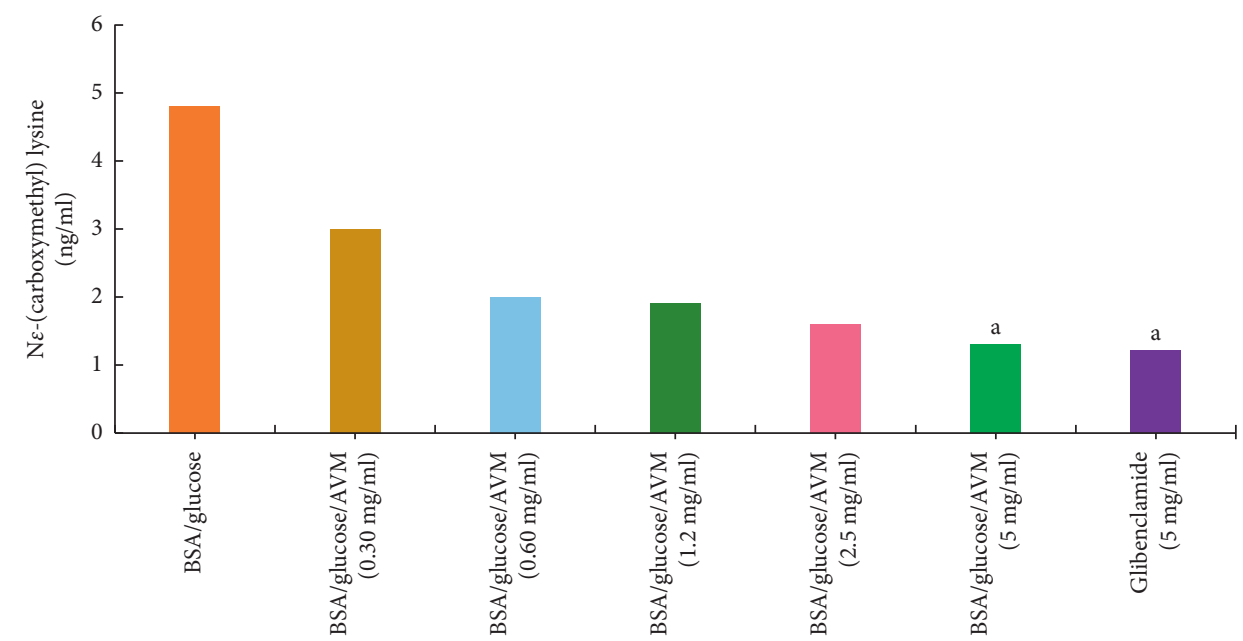

FIGURE 4: Effect of AVM on the inhibition of Ne-(carboxymethyl) lysine (CML) after four weeks of incubation. Each value represents the mean $\pm \operatorname{SEM}(n=3)$. ${ }^{\mathrm{a}} p<0.05$ compared to BSA/glucose.

TABLE 2: Effect of AVM on protein carbonyl content using the BSA/glucose system.

\begin{tabular}{|c|c|c|c|c|}
\hline \multirow{2}{*}{ Experimental groups } & \multicolumn{4}{|c|}{ Protein carbonyl content ( $\mathrm{nmol} / \mathrm{mg}$ protein) } \\
\hline & Week 1 & Week 2 & Week 3 & Week 4 \\
\hline BSA/glucose & $87.72 \pm 1.8$ & $88.59 \pm 1.4^{\mathrm{a}}$ & $88.91 \pm 1.4^{\mathrm{a}}$ & $89.15 \pm 1.2^{\mathrm{a}}$ \\
\hline BSA/glucose/AVM $(0.30 \mathrm{mg} / \mathrm{ml})$ & $86.44 \pm 0.7^{\mathrm{a}}$ & $87.19 \pm 0.8^{\mathrm{b}}$ & $87.09 \pm 1.1^{\mathrm{c}}$ & $86.92 \pm 1.1^{\mathrm{d}}$ \\
\hline BSA/glucose/AVM $(0.60 \mathrm{mg} / \mathrm{ml})$ & $86.31 \pm 1.1^{\mathrm{a}}$ & $87.04 \pm 1.7^{\mathrm{b}}$ & $86.53 \pm 1.4^{\mathrm{c}}$ & $86.37 \pm 1.1^{\mathrm{d}}$ \\
\hline BSA/glucose/AVM $(1.2 \mathrm{mg} / \mathrm{ml})$ & $85.11 \pm 9.9^{\mathrm{a}}$ & $86.17 \pm 1.4^{\mathrm{b}}$ & $86.81 \pm 1.2^{\mathrm{c}}$ & $85.07 \pm 0.9^{\mathrm{d}}$ \\
\hline BSA/glucose/AVM (2.5 mg/ml) & $84.33 \pm 1.2^{\mathrm{a}}$ & $85.94 \pm 0.8^{\mathrm{b}}$ & $84.18 \pm 1.4^{\mathrm{c}}$ & $84.66 \pm 1.1^{\mathrm{d}}$ \\
\hline BSA/glucose/AVM $(5 \mathrm{mg} / \mathrm{ml})$ & $83.24 \pm 0.6^{\mathrm{a}}$ & $84.33 \pm 0.7^{\mathrm{b}}$ & $83.57 \pm 0.7^{\mathrm{c}}$ & $82.88 \pm 0.6^{\mathrm{d}}$ \\
\hline $\mathrm{BSA} /$ glucose $/ \mathrm{AG}(5 \mathrm{mg} / \mathrm{ml})$ & $83.41 \pm 1.7^{\mathrm{a}}$ & $83.78 \pm 0.7^{\mathrm{b}}$ & $82.92 \pm 0.3^{\mathrm{c}}$ & $82.56 \pm 1.1^{\mathrm{d}}$ \\
\hline
\end{tabular}

Results are expressed as mean $\pm \operatorname{SEM}(n=3) .{ }^{\mathrm{a}} p<0.05$ when compared to BSA/fructose at week one; ${ }^{\mathrm{b}} p<0.05$ when compared to BSA/fructose at week two; ${ }^{c} p<0.05$ when compared to BSA/fructose at week three; ${ }^{\mathrm{d}} p<0.05$ when compared to BSA/fructose at week four.

the oxidation of sugars and/or by the oxidative degradation of Amadori products [17]. It has been reported that the administration of the ethanolic extract of $A$. vera gel helps prevent excessive free radical formation through various biochemical pathways and also reduces the glycosylation of enzymes [18]. 
TABLE 3: Effect of AVM on thiol group using the BSA/glucose system.

\begin{tabular}{lcccc}
\hline \multirow{2}{*}{ Experimental groups } & \multicolumn{3}{c}{ Thiol group (nmol/mg protein) } \\
& Week 1 & Week 2 & Week 3 & Week 4 \\
\hline BSA/glucose & $77.08 \pm 1.2$ & $75.38 \pm 0.07^{\mathrm{a}}$ & $75.88 \pm 0.05^{\mathrm{a}}$ & $70.05 \pm 0.08^{\mathrm{a}}$ \\
BSA/glucose/AVM $(0.30 \mathrm{mg} / \mathrm{ml})$ & $75.95 \pm 1.0$ & $77.73 \pm 0.09^{\mathrm{b}}$ & $79.16 \pm 0.07^{\mathrm{b}}$ & $79.52 \pm 0.06$ \\
BSA/glucose/AVM $(0.60 \mathrm{mg} / \mathrm{ml})$ & $77.08 \pm 0.51$ & $78.85 \pm 0.12^{\mathrm{b}}$ & $79.31 \pm 0.08^{\mathrm{b}}$ & $84.43 \pm 0.04^{\mathrm{d}}$ \\
BSA/glucose/AVM $(1.2 \mathrm{mg} / \mathrm{ml})$ & $76.29 \pm 0.83^{\mathrm{a}}$ & $79.79 \pm 0.09^{\mathrm{b}}$ & $80.46 \pm 0.11^{\mathrm{b}}$ & $86.60 \pm 0.09^{\mathrm{d}}$ \\
BSA/glucose/AVM $(2.5 \mathrm{mg} / \mathrm{ml})$ & $76.41 \pm 0.11^{\mathrm{a}}$ & $81.38 \pm 0.07^{\mathrm{b}}$ & $83.68 \pm 0.08^{\mathrm{b}}$ & $87.06 \pm 0.04^{\mathrm{d}}$ \\
BSA/glucose/AVM (5 mg/ml) & $76.68 \pm 0.08^{\mathrm{a}}$ & $83.29 \pm 0.05^{\mathrm{b}}$ & $85.61 \pm 0.09^{\mathrm{b}}$ & $89.12 \pm 0.06^{\mathrm{d}}$ \\
BSA/glucose/AG $(5 \mathrm{mg} / \mathrm{ml})$ & $76.52 \pm 0.08^{\mathrm{a}}$ & $77.37 \pm 0.02^{\mathrm{b}}$ & $77.56 \pm 0.04^{\mathrm{b}}$ & $78.08 \pm 0.09^{\mathrm{d}}$ \\
\hline
\end{tabular}

Results are expressed as mean \pm SEM $(n=3) .{ }^{\mathrm{a}} p<0.05$ when compared to BSA/fructose at week one; ${ }^{\mathrm{b}} p<0.05$ when compared to BSA/fructose at week two; ${ }^{c} p<0.05$ when compared to BSA/fructose at week three; ${ }^{\mathrm{d}} p<0.05$ when compared to BSA/fructose at week four.

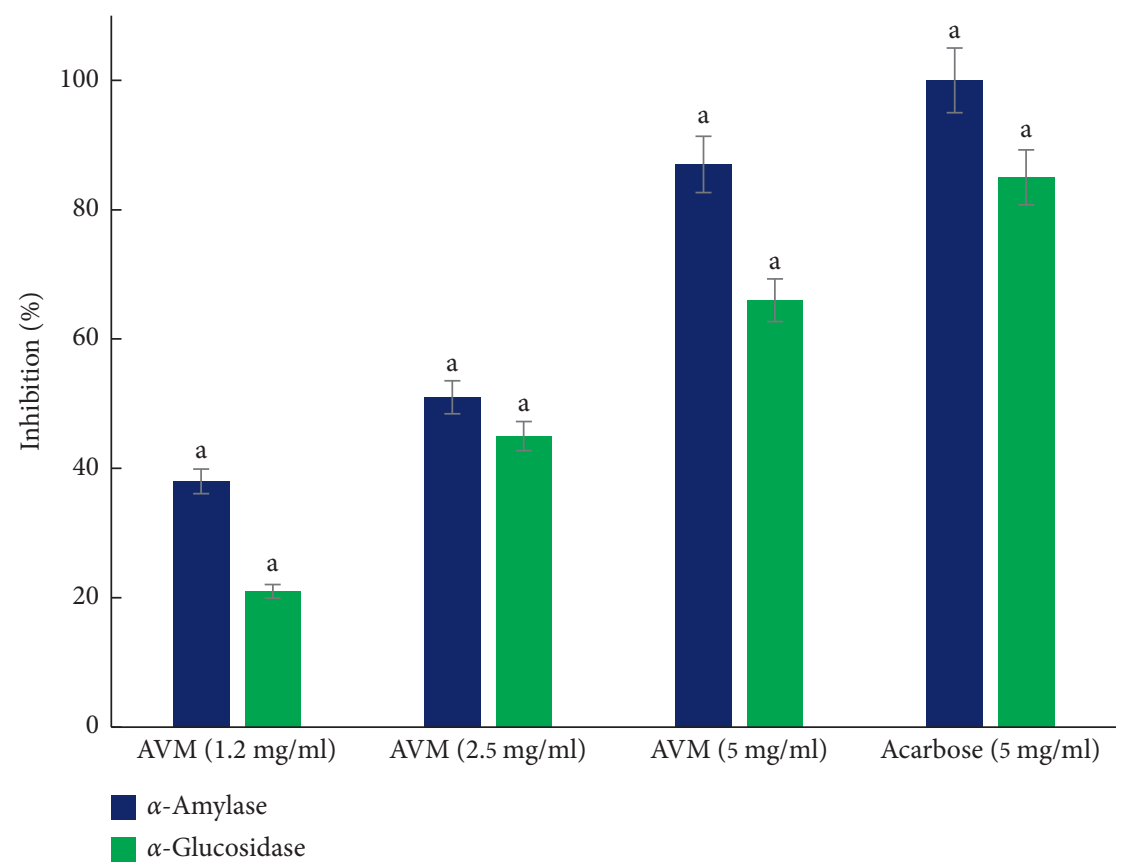

Figure 5: $\alpha$-Amylase and $\alpha$-glucosidase inhibition activity analysis of the methanol extract from Aloe vera. Values (mean \pm standard deviation) expressed as a percentage of enzymatic inhibition. AVM: methanol extract. Letters indicate statistical significance $(p<0.05)$.

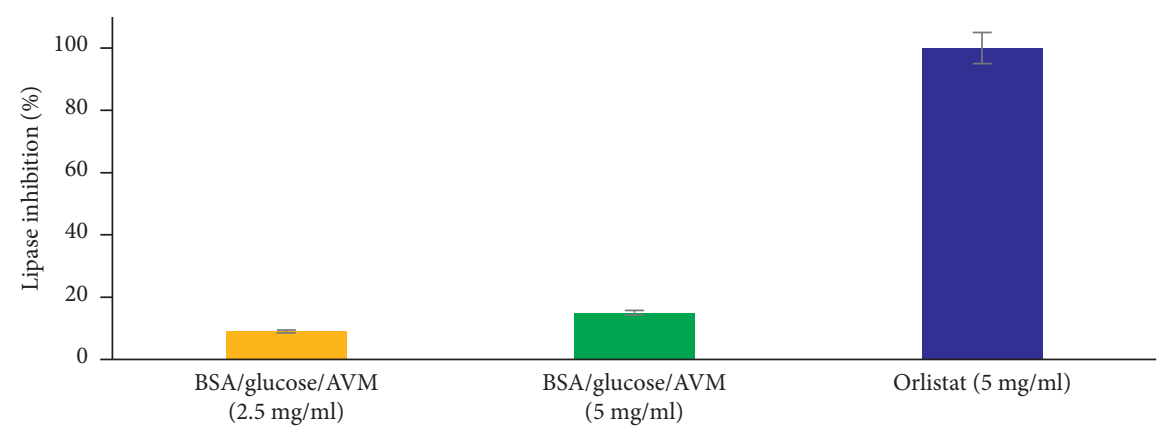

FIGURE 6: Lipase inhibition activity analysis of the methanol extract from Aloe vera. Values (mean \pm standard deviation) expressed as a percentage of enzymatic inhibition. AVM: methanol extract.

When blood sugar levels rise, the accumulation of fructose in different organs can occur. Both fructose and products derived from oxidation such as methylglyoxal can react with proteins and form AGEs [12, 15]. Arginine is one of the main targets of protein glycosylation by reactive carbonyls, which react with the guanidine group of the 
arginine to form AGEs [19]. Therefore, inhibiting the glycation of proteins and their oxidizing products is of paramount importance to prevent the complications of diabetes.

Our results show that the Aloe vera methanol extract (AVM) presents inhibitory activity in the formation of methylglyoxal and arginine, and this could be due to the presence of flavonoids [8]. It has been reported that flavonoids, as well as proanthocyanidins and phenolic acids, among others, are capable of inhibiting the glycation process $[20,21]$, since they inhibit the formation of AGEs by capturing precursors such as 1,2-dicarbonyl or interacting with glucose, preventing it from joining proteins.

High concentrations of postprandial glucose are a risk factor for microvascular and macrovascular complications in diabetes mellitus. AVM showed inhibitory activity of the enzymes $\alpha$-amylase and $\alpha$-glucosidase. Several flavonoids have been reported as inhibitors of these enzymes for their ability to bind to proteins [22], which may have contributed to the inhibitory effect of AVM. Previous studies of Aloe vera extract indicate that Aloe can act as a hypoglycemic agent through the potent inhibition of pancreatic amylase activity. This action decreases the breakdown of starch and offers good postprandial glycemic control [23].

AVM inhibited pancreatic lipase (PL), and it is known that insulin sensitivity is related to increased body fat [24], so inhibiting PL can be a way to inhibit fat absorption. Previous studies report that flavonoids inhibit PL, since these compounds can inactivate lipase through nonspecific binding of the enzyme, which could explain the inhibitory activity of AVM.

It has been reported that AG inhibits protein glycosylation, eliminating beta-dicarbonyls [2]. However, in clinical trials, it showed adverse effects such as gastrointestinal disorders, vasculitis, and abnormal liver function, while, in diabetic rats, it showed renal tumors [25].

Therefore, the discovery of inhibitors of the protein glycation reaction to reduce the formation of AGEs provides a promising therapeutic approach to prevent and treat diabetic complications.

Carboxymethyl lysine (CML) is formed by the oxidative degradation of Amadori products [19], and it is one of the best characterized AGEs chemically, which has been used as the main marker of AGEs in many studies [26]. Recent research has shown that CML can interact with the RAGE receptor by inactivating signaling pathways, which leads to the expression of proinflammatory genes [27]. CML has been found in the blood vessels of the retina in people with type 2 diabetes mellitus, and it has been linked to the degree of retinopathy [28], and therefore, it is important to find compounds that inhibit the formation of CML. In this regard, AVM showed the ability to reduce the formation of CML significantly, which could be an alternative to reduce the complications of diabetes associated with AGEs.

Protein carbonyl compounds are formed by the oxidation of amino acid residues, which, together with the protein thiol groups, are considered as markers of the modification of proteins by oxidation. This modification is measured by the formation of hydrazone 2,4-dinitrophenylhydrazine adducts (DNPH) [2]. In this study, it was observed that
AVM is effective in eliminating carbonyls bound to proteins and increasing the concentration of thiol protein groups, helping to prevent oxidative damage in proteins.

\section{Conclusions}

Aloe vera methanol extract effectively inhibited the glycation reaction of proteins in the $\mathrm{BSA} /$ glucose system, possibly due to the oxidative degradation of fructosamine; however, it is necessary to determine the mechanism of action by which AVM inhibits AGEs. More research is required to describe the interactions of AVM with the enzymes $\alpha$-amylase, $\alpha$-glucosidase, and pancreatic lipase to provide a basis for the development of new natural inhibitors.

\section{Data Availability}

The data used to support the findings of this study are included within the article.

\section{Conflicts of Interest}

The authors declare that there are no conflicts of interest regarding the publication of this paper.

\section{References}

[1] L. Zeng, H. Ding, X. Hu, G. Zhang, and D. Gong, "Galangin inhibits $\alpha$-glucosidase activity and formation of non-enzymatic glycation products," Food Chemistry, vol. 271, pp. 7079, 2019.

[2] M. M. Joglekar, L. N. Bavkar, S. Sistla, and A. U. Arvindekar, "Effective inhibition of protein glycation by combinatorial usage of limonene and aminoguanidine through differential and synergistic mechanisms," International Journal of Biological Macromolecules, vol. 99, pp. 563-569, 2017.

[3] N. J. Kellow and M. T. Coughlan, "Effect of diet-derived advanced glycation end products on inflammation," Nutrition Reviews, vol. 73, no. 11, pp. 737-759, 2015.

[4] A. Muñiz, E. Garcia, D. Gonzalez, and L. Zuñiga, "Antioxidant activity and in Vitro antiglycation of the fruit of spondias purpurea," Evidence-Based Complementary and Alternative Medicine, vol. 2018, Article ID 5613704, 7 pages, 2018.

[5] R. G. Khalifah, J. W. Baynes, and B. G. Hudson, "Amadorins: novel post-Amadori inhibitors of advanced glycation reactions," Biochemical and Biophysical Research Communications, vol. 257, no. 2, pp. 251-258, 1999.

[6] L. Zhang, Z.-C. Tu, X. Xie et al., "Antihyperglycemic, antioxidant activities of two Acer palmatum cultivars, and identification of phenolics profile by UPLC-QTOF-MS/MS: new natural sources of functional constituents," Industrial Crops and Products, vol. 89, pp. 522-532, 2016.

[7] L. Langmead, R. J. Makins, and D. S. Rampton, "Anti-inflammatory effects of aloe vera gel in human colorectal mucosa in vitro," Alimentary Pharmacology and Therapeutics, vol. 19, no. 5, pp. 521-527, 2004.

[8] B. Benzidia et al., "Chemical composition and antioxidant activity of tannins extract from green rind of Aloe vera (L.) Burm. F." Journal of King Saud University-Science, vol. 31, no. 4, pp. 1175-1181, 2018.

[9] A. A. Maan, A. Nazir, M. K. I. Khan et al., "The therapeutic properties and applications of Aloe vera: a review," Journal of Herbal Medicine, vol. 12, pp. 1-10, 2018. 
[10] R. M. P-Gutierrez, "Inhibitory activities of guaianolides from the seeds of byrsonima crassifolia against protein glycation in vitro," Medicinal Chemistry, vol. 5, no. 5, pp. 217-225, 2015.

[11] S. Adisakwattana, W. Sompong, A. Meeprom, S. Ngamukote, and S. Yibchok-Anun, "Cinnamic acid and its derivatives inhibit fructose-mediated protein glycation," International Journal of Molecular Sciences, vol. 13, no. 2, pp. 1778-1789, 2012.

[12] W. Wang, Y. Yagiz, T. J. Buran, C. d. N. Nunes, and L. Gu, "Phytochemicals from berries and grapes inhibited the formation of advanced glycation end-products by scavenging reactive carbonyls," Food Research International, vol. 44, no. 9, pp. 2666-2673, 2011.

[13] A. B. Justino, M. N. Pereira, D. D. Vilela et al., "Peel of araticum fruit (Annona crassiflora Mart.) as a source of antioxidant compounds with $\alpha$-amylase, $\alpha$-glucosidase and glycation inhibitory activities," Bioorganic Chemistry, vol. 69, pp. 167-182, 2016.

[14] M. N. Pereira, A. B. Justino, M. M. Martins et al., "Stephalagine, an alkaloid with pancreatic lipase inhibitory activity isolated from the fruit peel of Annona crassiflora Mart." Industrial Crops and Products, vol. 97, pp. 324-329, 2017.

[15] A. B. Justino, N. C. Miranda, R. R. Franco, M. M. Martins, N. M. d. Silva, and F. S. Espindola, "Annona muricata Linn. leaf as a source of antioxidant compounds with in vitro antidiabetic and inhibitory potential against $\alpha$-amylase, $\alpha$-glucosidase, lipase, non-enzymatic glycation and lipid peroxidation," Biomedicine \& Pharmacotherapy, vol. 100, pp. 83-92, 2018.

[16] N. Jariyapamornkoon, S. Yibchok-anun, and S. Adisakwattana, "Inhibition of advanced glycation end products by red grape skin extract and its antioxidant activity," BMC Complementary and Alternative Medicine, vol. 13, no. 1, p. 171, 2013.

[17] A. Ardestani and R. Yazdanparast, "Cyperus rotundus suppresses AGE formation and protein oxidation in a model of fructose-mediated protein glycoxidation," International Journal of Biological Macromolecules, vol. 41, no. 5, pp. 572578, 2007.

[18] M. H. Radha and N. P. Laxmipriya, "Evaluation of biological properties and clinical effectiveness of aloe vera: a systematic review," Journal of Traditional and Complementary Medicine, vol. 5, no. 1, pp. 21-26, 2015.

[19] N. Ahmed, "Advanced glycation endproducts-role in pathology of diabetic complications," Diabetes Research and Clinical Practice, vol. 67, no. 1, pp. 3-21, 2005.

[20] N. T. Florence, M. Z. Benoit, K. Jonas et al., "Antidiabetic and antioxidant effects of Annona muricata (Annonaceae), aqueous extract on streptozotocin-induced diabetic rats," Journal of Ethnopharmacology, vol. 151, no. 2, pp. 784-790, 2014.

[21] P. C. Feng, L. J. Haynes, K. E. Magnus, J. R. Plimmer, and H. S. A. Sherratt, "Pharmacological screening of some west Indian medicinal plants," Journal of Pharmacy and Pharmacology, vol. 14, no. 1, pp. 556-561, 1962.

[22] G. J. Mcdougall and D. Stewart, "The inhibitory effects of berry polyphenols on digestive enzymes," BioFactors, vol. 23, no. 4, pp. 189-195, 2005.

[23] A. Mourad, H. Abo-Youssef, B. Anwar, and S. Messiha, "Beneficial effects of Aloe vera in treatment of diabetes: comparative in vivo and in vitro studies," Bulletin of Faculty of Pharmacy, vol. 51, no. 1, pp. 7-11, 2013.

[24] A. Golay and J. Ybarra, "Link between obesity and type 2 diabetes," Best Practice \& Research Clinical Endocrinology \& Metabolism, vol. 19, no. 4, pp. 649-663, 2005.
[25] N. Rabbani and P. J. Thornalley, "Advanced glycation end products in the pathogenesis of chronic kidney disease," Kidney International, vol. 93, no. 4, pp. 803-813, 2018.

[26] Y. Chen, S. Tang, Y. Chen et al., "Structure-activity relationship of procyanidins on advanced glycation end products formation and corresponding mechanisms," Food Chemistry, vol. 272, pp. 679-687, 2019.

[27] M.-P. Wautier, P.-J. Guillausseau, and J.-L. Wautier, “Activation of the receptor for advanced glycation end products and consequences on health," Diabetes \& Metabolic Syndrome: Clinical Research \& Reviews, vol. 11, no. 4, pp. 305309, 2017.

[28] S.-Y. Goh and M. E. Cooper, "The role of advanced glycation end products in progression and complications of diabetes," The Journal of Clinical Endocrinology \& Metabolism, vol. 93, no. 4, pp. 1143-1152, 2008. 